\title{
DIPENUHI DI DALAM KRISTUS PERSPEKTIF SURAT KOLOSE SEBAGAI LANDASAN BAGI GEREJA DALAM MELAYANI MASYARAKAT
}

\author{
ALBERTH DARWONO SARIMIN \\ STT BALA KESELAMATAN PALU \\ JL. TOWUA NO 80 PALU
}

abesarimin@gmail.com

\begin{abstract}
The existensi of the church in this world because of mission mandate of Jesus Christ. To know how the church can serve community well, in this paper the Colossians become a focus of research and the reason to choose this letter was the collosians consist of plural community.

The purpose of this paper is to look at how religion sociology influences social life and theology can drive social change system. While the research method that was used is library research

Social structure that is formed in Colossian community provides an opportunity for the growth of false teaching and seeing this social structure strongly built in Colossian Paul raised a theology of fullness of God in Christ and belivers are fulfilled in Christ. In other words that the supremacy of Christ in everything and over everything The existence of the church has a role to drive social system and to apply that system Christ should be supremed, supremacy of Christ is above the mission and the church has a strategy to carry out its mission. In other words, to be able to serve community, the church should place Christ over everything and have a strategy in carrying out its mission so that the church which is a sub system in the community able to move a larger system
\end{abstract}

Keywords: fulllness, fulfilled, supremacy, christ

\begin{abstract}
ABSTRAK
Gereja ada dalam dunia ini adalah karena mandat misi dari Yesus Kristus. Untuk melihat bagaimana gereja dapat melayani masyarakat dengan baik maka dalam tulisan ini surat Kolose menjadi fokus penelitian dan alasan memilih surat tersebut adalah masyarakat Kolose terdiri dari masyarakat majemuk.

Tujuan dari penulisan ini adalah melihat bagaimana peran sosiologi (dalam pengertian studi tentang hidup bermasyarakat) memengaruhi kehidupan sosial dan teologi yang diangkat dalam menggerakan sistim perubahan sosial tersebut. Sedangkan metode penelitian yang digunakan adalah penelitian kepustakaan.

Struktur sosial yang terbentuk dalam masyarakat di Kolose memberikan peluang tumbuhnya ajaran-ajaran sesat dan melihat struktur sosial yang begitu kuat terbangun di kolose maka Paulus mengangkat teologi seluruh kepenuhan Allah ada dalam Kristus dan orang percaya dipenuhi dalam Kristus. Dengan kata lain bahwa supremasi Kristus ada dalam segala sesuatu dan atas segala sesuatu

Eksistensi gereja sangat berperan dalam menggerakan sistim sosial sehingga dalam melaksanakan hal tersebut gereja menjadikan Kristus bersupremasi di dalamnya, supremasi Kristus di atas misi dan gereja memiliki strategi dalam menjalankan mandat misinya. Dengan kata lain, untuk dapat melayani masyarakat maka gereja harus menempatkan Kristus atas segala sesuatu dan memiliki strategi dalam menjalankan misinya sehingga gereja yang adalah subsistem dalam masyarakat mampu menggerakan sebuah sistem yang lebih besar.
\end{abstract}

Kata Kunci: kepenuhan, dipenuhi, supremasi, kristus

\section{Pendahuluan}

Gereja ada dan dipanggil untuk melaksanakan misi yang mulia dari Yesus Kristus atau di kenal dengan amanat agung. Dalam melaksanakan tugasnya, gereja yang ada di tengah-tengah masyarakat dan berperan aktif sehingga mandat misi tersebut dapat dilaksankan dalam berbagai bentuk. Namun 
tidak dapat dipungkiri bahwa masyarakat memiliki sistem dan sub sistem yang terbangun dengan kuat melalui nilai-nilai dan tradisi yang dibangunnya. Apalagi konteks masyarakat kita adalah masyarakat yang majemuk atau plural.

Dalam menjalankan mandat misi ini gereja sering mengalami tantangan, baik tantangan yang datang dari luar maupun dari dalam gereja sendiri dan tidak dapat dipungkiri bahwa dalam situasi yang demikian gereja terus memperluas wilayah pelayanannya. Tantangan dari luar, salah satunya dapat dilihat melalui fenomena penolakan terhadap eksistensi gereja di suatu tempat, baik yang sudah ada maupun yang akan memulai persekutuan. Akibatnya peristiwa ini mengundang perhatian dari berbagai pihak baik dari organisasi gereja maupun dari pemerintah. Dalam kondisi yang demikian maka usaha yang dilakukan adalah gereja berusaha mempertahankan dirinya dan seolah olah tidak mampu memberitakan pesan utama dari eksistensinya. Walaupun kesan seolah-olah gereja mempertahankan dirinya dapat dilihat dari berbagai faktor namun ini menjadi kewaspadaan. Bila hanya mempertahankan maka misi yang seperti ini dikritisi oleh Bonhoeffer sebagaimana di kutip oleh Bosch. Gereja kita, yang telah berjuang pada tahun-tahun ini hanya untuk mempertahankan dirinya sendiri, seolah-olah itulah tujuan dirinya, tidak mampu menyampaikan pesan perujukan dan penebusan kepada umat manusia dan dunia. Karenanya kata-kata kita sebelumnya pasti akan kehilangan kekuatannya dan berhenti dan keberadaan kita sebagai orang Kristen di masa kini akan terbatas pada dua hal: berdoa dan Tindakan yang benar (righteous act $)^{1}$. Gereja harusnya menjadi yang inklusif, melenyapkan keterasingan, menghancurkan dinding-dinding pemisah, membebaskan yang tertindas, gereja harus menjadikan Kristus sebagai pusat dalam mengemban madatnya sehingga benar-benar misi sebagai Imago Dei dan Misio Dei terlihat nyata dalam pelayanannya.

Fenomena gereja yang cenderung mempertahankan eksistensinya dan seolah-olah lupa pada tujuan pewartaan keselamatan bagi umat manusia salah satu cirinya dapat dilihat akhir-akhir ini. Gereja masih berkutat dengan debat teologinya di tengah-tengah wabah yang melanda dan berakibat pada masalah sosial lain. Atas kejadian ini direktur jenderal bimbingan masyarakat Kristen mengeluarkan himbauan melalui surat dengan nomor: B-172/DJ.IV/BA.01. 1/04/2020 tentang himbauan untuk menghentikan perdebatan teologis di media sosial. Dalam situasi seperti ini harusnya gereja dari berbagai denominasi bersatu dalam pewartaan tentang pengharapan di masa yang sulit dan keselamatan di dalam Kristus. Melalui tulisan ini, khususnya kajian surat kepada orang-orang di Kolose menjadi bahan acuan bagaimana seharusnya eksistensi gereja ada dalam masyarakat dalam pewartaan keselamatan melalui misi yang diemban.

Tujuan penulisan ini adalah untuk melihat bagaimana jemaat yang ada di Kolose memengaruhi kehidupan sosial dan teologi apa yang diangkat dalam menggerakan sistim perubahan sosial tersebut sehinggga akan memunculkan sistim kehidupan masyarakat yang baru dan menjadi role model bagaimana gereja dapat melakukan perubahan sosial dalam kehidupan masyarakat yang sudah memiliki sistem dan subsistem.

Metode penelitian yang digunakan dalam penelitian ini adalah penelitian kepustakaan. Penelitian ini merupakan jenis riset kepustakaan (library research). Apa yang disebut dengan riset kepustakaan atau sering juga di sebut studi pustaka, ialah serangkaian kegiatan yang berkenan dengan metode pengumpulan data pustaka, membaca dan mencatat serta mengolah bahan penelitian ${ }^{2}$. Berkaitan dengan metode penelitian ini maka penulis menggunakan Alkitab dan buku-buku yang berkaitan dengan sosiologi serta tafsir surat kolose sebagai bahan penelitan

1 . David J. Bosch, Transformasi Misi Kristen, Sejarah Teologi Misi yang Mengubah dan Berubah (Jakarta: Gunung Mulia, 2015), 797

${ }^{2}$ Meztika zed, Metode Penelitian Kepustakaan (Jakarta: Yayasan Obor Indonesia, 2008) ,3 


\section{Struktur Masyarakat di Kolose}

Jemaat-jemaat yang ada di dalam Perjanjian Baru adalah jemaat-jemaat yang dibangun oleh para rasul atau oleh orang percaya yang menyebar karena peristiwa penganiayaan di Yerusalem atau jemaat yang dibangun melalui pemberitaan Injil oleh rasul Paulus. Di tempat mereka melarikan diri di situlah mereka membangun jemaat. Salah satu contoh jemaat yang dibangun bukan oleh para rasul adalah jemaat Kolose. Tidak dapat dipungkiri bahwa struktur sosial dan kehidupannya turut memengaruhi tumbuh dan berkembangnya gereja atau sebaliknya mengalami hambatan. Dengan melihat tulisan rasul Paulus baik itu surat penggembalaan, surat pribadi atau tulisan rasul-rasul yang lainnya ada tantangan dalam jemaat maupun dari luar gereja. Tantangan tersebut tidak lepas dari masalah sosiologi atau kehidupan sosial masyarakat di mana jemaat hidup dan ini memberikan ciri tersendiri dari tiap-tiap jemaat yang ada di Perjanjian Baru.

Tulisan ini akan menguraikan surat Kolose berdasarkan tinjauan teologi sosial sehingga dapat mengenali masalah-masalah yang ada dan memahami latar belakang rasul Paulus menuliskan surat tersebut serta teologi apa yang dimunculkan dalam menghadapi tantangan yang ada. Oleh karenanya diperlukan sebuah pemahaman apa yang dimaksud dengan sosiologi.

Sosiologi merupakan studi mengenai masyarakat dalam suatu sistem sosial. ${ }^{3}$ Sosiologi secara umum merupakan studi sistematik terhadap masyarakat manusia dengan menekankan pada kelompok sosial beserta berbagai konsekuensi dari kehidupan bersama. Sosiologi dapat diidentikkan dengan studi tentang struktur sosial yang merupakan konsekuensi utama kehidupan bersama tersebut ${ }^{4}$.Sedangkan teori sosoiologi fungsional memiliki asumsi utama yaitu melihat masyarakat sebagai sebuah sistem yang di dalamnya terdapat subsistem ${ }^{5}$. Sedangkan teori sosiologi modern menyajikan kepada sesuatu yang lain, yang berbeda dengan teori sosiologi pada awal mula. Jameson mengatakan demikian tentang sosiologi modern khususnya post-modernisasi. Suatu citra tentang post-modernitas di mana manusia terkatung-katung dan tak mampu memahami sistem kapitalis multinasional atau pertumbuhan kultur yang meledak-ledak di tempat mereka hidup ${ }^{6}$.

Dengan demikian maka keberadaan jemaat yang ada di Kolose ada dalam sebuah sistem masyarakat dan tidak dapat dilepaskan oleh kultur yang tumbuh dalam sistem maupun sub sistem orangorang yang ada di Kolose. Dan masalah ini mempengaruhi pertumbuhan jemaat yang ada di Kolose. Bila dikaji secara khusus maka akan terlihat bagaimana jemaat di Kolose dapat menggerakan perubahan sosial yang memengaruhi kehidupan sosial kemasyarakatan yang ada di Kolose dan peran apa yang terlihat dari perubahan sosial tersebut dan sehingga dapat memunculkan warna yang baru dalam kehidupan sosial orang-orang yang ada di Kolose.

Kehidupan jemaat yang ada di Kolose, sebagaimana telah disebutkan sebelumnya dalam hubungannya dengan kehidupan sosial masyarakat yang ada di sana, memiliki karakter yang berbeda dengan jemaat-jemaat yang lain yang ada di Perjanjian Baru. Hal ini tidak dapat dilepaskan dengan stuktur sosial yang sudah terbangun sebelum Injil diberitakan kepada orang-orang di Kolose. Olehnya diperlukan pemahaman kehidupan sosial yang terbangun di Kolose. Dalam hal ini struktur sosial, ekonomi, politik dan juga kondisi geografis memiliki peran penting dalam kehidupan jemaat.

\footnotetext{
${ }^{3}$ Nanang Martono, Sosiologi Perubahan Sosial, Perspektif Klasik, Modern, Posmodern dan Poskolonial (Jakarta: PT RajaGrafindo Persada,2016) 1

4 Sindung Haryanto. Sosiologi Agama dari Klasik Hingga Postmodern (Yogyakarta: Arr- Ruzz Media, 2015)

${ }^{5}$ Nanang Martono, Sosiologi Perubahan Sosial, Perspektif Klasik, Modern, Posmodern dan Poskolonial (Jakarta: PT RajaGrafindo Persada,2016) 35

${ }^{6}$ George Ritzer, Douglas J. Goodman. Teori Sosiologi Moderen (Jakarta: Kencana Prenada Media Group, 2004), 638
} 
Kota Kolose terletak di sebuah lembah dan dikelilingi oleh pegunungan. Di perkirakan di Firgia tidak jauh dari Laodikia dan Hierapolis (4:13). Kota Kolose terletak kira-kira $160 \mathrm{~km}$ dari kota Efesus, di tepi sungai Lykus. Dahulu kota ini sungguh terkemuka, tetapi pada masa Paulus keadaanya kurang menarik, dan kedudukannya sebagai salah satu kota di Asia kecil sudah tidak begitu penting lagi ${ }^{7}$. Hal ini disebabkan oleh karena perubahan sosial yang terjadi dan hingga saat ini tidak ditemukan puingpuing dari kota itu. Di abad modern ini Kolose terletak di negara Turki. Tanah dari gunung berapi yang tersebar di kota Kolose membuat daerah ini subur. . . dan sangat tepat untuk memelihara domba. Dengan tersedianya bulu domba, industri pakaian berkembang baik dan menyebabkan perekonomian berkembang dan menjadikan perekonomian setempat bertumbuh ${ }^{8}$.

Orang-orang yang ada di Kolose adalah masyarakat yang terdiri dari berbagai suku bangsa. Penduduk kota Kolose terdiri dari berbagai bangsa. Sebagian besar warga kota adalah orang pribumi Frigia, yang terkenal sebagai penganut ilmu klenik (mistik) dan bersifat tidak mantap. Sejumlah besar orang Yunani juga menghuni kota itu. Bahasa Yunani dan kebudayaan Yunani menonjol di lembah Lycus. Di Kolose terdapat sebuah perkampungan orang Yahudi yang agak besar' ${ }^{9}$ Jadi paling tidak ada tiga kelompok besar suku yang mendiami Kolose. Hal ini menyebabkan warisan agama tua masih dipraktikan di Kolose. Wright menggambarkan keadaan sosial masyarakat yang ada di Kolose adalah sepertinya orang-orang Kolose memiliki hubungan dalam mempraktikkan berbagai agama yang mencirikan agama timur dekat pada saat itu. Dalam masyarakat ini dewa-dewa tua dari budaya Yunani masih memiliki pengikut, sebagaimana juga agama-misteri yang menjanjikan masuk pada rahasia dunia yang lebih tinggi bagi mereka yang bermohon dengan cara yang tepat. ${ }^{10}$ Dengan pengaruh praktik agama timur, terlihat bahwa agama timur dekat sangat kuat pengaruhnya bagi orang-orang yang di Kolose dengan demikian dalam struktur masyarakat yang ada di Kolose, selain gereja, ada kelompokkelompok yang ada di masyarakat yang memiliki cara penyembahannya sendiri sehingga dapat dikatakan bahwa di kota Kolose praktik penyembahan kepada dewa-dewa masih begitu kuat, kebudayaan Yunani yang begitu berpengaruh pada saat itu dihidupi oleh orang-orang Yunani yang ada di Kolose dan alasan inilah yang menyebabkan Paulus menulis suratnya.

Selain itu masalah ajaran seperti gnostik masih dipraktekan dalam kehidupan masyarakat yang ada di Kolose dan Paulus menyebutnya dengan istilah lain seperti filsafat ( 2:8), kata-kata yang indah (2:4). Semakin nyata kemiripan ajaran gnostik terlihat di Kolose dengan adanya aturan masalah makanan dan minuman, sabath dan aturan-aturan Yahudi yang lain yang terdapat juga di Galatia 3:2325. Di sini terlihat bahwa kebudayaan Yunani dan tradisi Yahudi memengaruhi kehidupan orang-orang percaya.

Melihat kondisi yang ada sebenarnya jemaat yang ada di Kolose sebagian besar berasal bukan Yahudi tetapi mereka telah dipengaruhi oleh ajaran yang dicampur adukan antara aturan-aturan dan Injil dan juga pengaruh agama kafir maka dapat digambarkan bahwa di Kolose terjadi pengaruh eksternal yang begitu kuat terhadap gereja sehingga mereka yang sudah dipengaruhi perlu untuk dibimbing kembali kepada ajaran yang benar yaitu Injil Yesus Kristus dan meninggalkan bentuk-bentuk penyembahan baik pengaruh filsafat dunia, penyembahan kepada dewa-dewa kafir, aturan-aturan yang masih dipegang teguh dari Taurat, ajaran-ajaran sesat dan lain-lain.

Tidak dapat dipungkiri bahwa pengaruh Yahudi begitu kuat pada zaman itu. Walupun Israel sendiri pernah diduduki oleh beberapa negara tetapi orang-orang Yahudi sempat membangun koloni di

\footnotetext{
${ }^{7}$ Adina Chapman. Pengantar Perjanjian Baru (Bandung: Yayayasan Kalam Hidup, 1995) 99

${ }^{8}$ Luther E. Schwartzkopf, The Letter of Paul to the Collossian, Living Way Bible Study (La Mirada Canada, 2014), 4

${ }^{9}$ Jarry Autrey. Surat Kiriman Penjara (Malang: Gandum Mas, 2001), 154

${ }^{10}$ N.T Wright. Tyndale New Testament Commentaries, Colossians and Philemon (Englland: Inter Varsity Press, 1997) 22
} 
beberapa tempat. Banyak orang Yahudi di Kolose menjadikan daerah sekitarnya koloni Yahudi yang dibangun permulaan abad kedua sebelum masehi. Semua bukti menyatakan bahwa jemaat dibangun oleh orang non Yahudi dan Filemon adalah salah satu anggotanya ${ }^{11}$.

Bila dilihat dari perspektif sosiologi sebagaimana yang telah disebutkan di atas, terutama yang disebutkan oleh Martono dan Haryanto maka masyarakat yang ada di Kolose adalah masyarakat yang menghidupi tradisi ilmu klenik, kebudayaan Yunani, tradisi Yahudi dan pengaruh agama timur dekat dengan penyembahan kepada dewa-dewa berimplikasi terhadap kehidupan persekutuan orang-orang percaya di Kolose dengan mencampur adukan Injil dan tradisi dari agama-agama lain, Seperti gnostik, aturan makan dan minum dan juga filsafat. Inilah yang terlihat dalam kehidupan gereja di Kolose di tengah-tengah kehidupan komunitas Kolose secara umum.

\section{Tradisi yang tumbuh di Kolose}

Gereja yang ada di Kolose adalah gereja yang tumbuh dengan baik dan belum lama berdiri. Walupun jemaat tersebut tergolong muda namun pertumbuhannya sangat signifikan. Namun di tengahtengah pertumbuhan tersebut ada tradisi-tradisi yang terus dipegang bahkan memengaruhi kehidupan gereja di Kolose. Praktik keagamaan yang ada di Kolose tidak dapat dilepaskan oleh agama yang terdahulu yang telah memengaruhi hidup orang-orang di Kolose dan ini semacam warisan yang secara terus menerus di hidupi dan menjadi budaya yang tumbuh di Kolose. Adapaun tradisi itu adalah sebagai berikut:

\subsection{Filsafat}

Di dalam suratnya, Paulus dengan tegas menyebutkan beberapa hal yang memengaruhi kehidupan jemaat. Masalah diperdaya dengan kata-kata yang indah (2:4). Pada bagian ini, Paulus berusaha untuk melindungi orang-orang percaya di Kolose agar jemaat yang baru tumbuh dan berkembang dengan baik tidak mudah dipengaruhi oleh ajaran-ajaran sesat. Ajaran-ajaran ini Paulus telah temui dan tumbuh dalam kehidupan di beberapa jemaat. Kata-kata yang indah merupakan salah satu filsafat dunia. Benson commentary mengatakan demikian: Kata-kata yang indah- filsafat manusia dan ilmu pengetahuan yang salah dan tidak menarik anda dari kebenaran yang sejati yang terdapat di dalam Yesus Kristus ${ }^{12}$. Penegasan Paulus agar jemaat yang baru bertumbuh tidak dipengaruhi oleh filsafat dunia yang berkembang pada saat itu. Masalah Filsafat dunia lebih ditegaskan lagi pada (2:8). . . jangan ada yang menawan kamu dengan filsafatnya yang kosong dan palsu menurut ajaran turuntemurun dan roh-roh dunia tetapi tidak menurut Kristus. Sebenarnya filsafat itu sendiri tidak salah. Bahkan menjadi subyek yang penting untuk dipelajari namun menjadi salah ketika orang-orang di Kolose menempatkan filsafat dunia dicampur adukan dengan Firman Tuhan sehingga supremasi Kristus tidak dihidupi dalam kehidupan berjemaat dan bermasyarakat.

\subsection{Tradisi Yahudi}

Sebagaimana telah disebutkan bahwa penduduk Kolose sebagian adalah orang-orang Yahudi walaupun mereka hanyalah sekelompok kecil, tetapi tradisi Yahudi masih begitu kuat mempengaruhi kehidupan jemaat dan masyarakat yang ada. Ritual-ritual keagamaan begitu kuat melekat dalam hidup

${ }^{11}$ Luther E. Schwartskopf, The Letter of Paul to the Collossian, Living Way Bible Study (La Mirada Canada, 2014), 4

12 Benson Commentary Colossian 2:4-5, diakses 22 Agustus 2019 https://biblehub.com/commentaries/colossians/2-4.htm 
mereka dan ini yang menyebabkan adanya dua sisi hidup keagamaan yang berbeda. Satu sisi adalah ritual aturan keagamaan dan satu sisi adalah Injil.

Tradisi Yahudi ini menjadi sebuah pengajaran yang salah sebab Injil masih dicampur adukan dengan aturan-aturan Yahudi. Hal itu terlihat dalam (2:11). Di dalam Dia kamu telah disunat, bukan dengan sunat yang dilakukan oleh manusia, tetapi dengan sunat Kristus yang terdiri dari penanggalan akan tubuh yang berdosa. Permasalahan sunat atau tak bersunat merupakan pengaruh Yahudi secara umum terhadap orang-orang Yahudi Kristen dan juga orang-orang yang dapat dipengaruhinya. Di Galatia, Paulus harus menjelaskan pemberitaan Injil kepada orang-orang bersunat dan tak bersunat (Gal 2:7). Di sini terlihat bahwa sekelompok kecil masyarakat atau dalam sosiologi sosial di sebut dengan sub masyarakat memiliki pengaruh yang kuat terhadap kehidupan sosial orang-orang yang ada di Kolose.

\subsection{Aturan makanan dan minuman dan masalah hari raya}

Masalah makanan dan minuman serta hari-hari raya juga muncul dalam kehidupan sosial masyarakat yang ada di Kolose. Aturan serta perayaan ini masih ada hubungannya dengan hukum agama Yahudi sebagaimana yang dicatat dalam Kolose 2:16. Paulus menegaskan bahwa orang-orang di Kolose harus meninggalkan kebiasaan atau tradisi ini sebab orang percaya tidak lagi hidup di bawah kuasa hukum Taurat, tetapi pada kasih karunia yang Tuhan sediakan bagi setiap orang. Jadi komunitas orang-orang Kolose adalah komunitas yang terbagi lagi dalam sub-sub komunitas dan pada masingmasing komunitas memiliki tradisi tersendiri dipegang dan dihidupi. Pengajaran ini akan memiliki pengaruh bukan hanya untuk orang-orang Kristen di Kolose percayai tetapi juga bagaimana kehidupan mereka sehari-hari. Apa yang mereka makan dan minum dan bagaimana mereka beribadah dari minggu ke minggu ${ }^{13}$. Jelas bahwa sub-sub komunitas yang ada di Kolose memiliki struktur sosial, tradisi dan iman yang lain. Dan eksistensi jemaat yang ada di Kolose dikelilingi oleh struktur kehidupan sosial yang demikian.

\section{Beribadah kepada Malaikat}

Disebutkan juga bahwa beribadah kepada malaikat serta berkanjang pada penglihatanpenglihatan (2:18) terjadi di Kolose. Ada dua hal yang diangkat dalam ayat ini berkaitan dengan tradisi yang masih dihidupi oleh orang-orang di Kolose. Beribadah kepada malaikat-malaikat dan berkanjang pada penglihatan-penglihatan. Tradisi yang masih tumbuh di kalangan orang-orang Kolose ini adalah pengaruh dari Yahudi maupun Yunani khususnya pada zaman Plato dan juga telah dipraktikan oleh beberapa orang Kristen pada awal mula.

Penyembahan kepada malaikat "adalah praktik yang sejak semula dilakukan oleh beberapa orang yang menyebut dirinya Kristen. Dan kemudian berlanjut di Frigia dan Pisidia; dalam waktu yang lama. Beberapa menyebut Simon Magus, dan yang lain Cerinthus, penulis penyembahan berhala ini; tetapi bukan hanya cabang dari filsafat Platonis, dan bagian dari filsafat itu dan tipu daya yang sia-sia sebelum disebutkan di (Kolose 2: 8), yang mungkin orang-orang ini meminjam dari orang-orang Yunani, tetapi merupakan gagasan dan praktik yang dilakukan oleh orang Yahudi: sebelum ditaklukan oleh bangsa Babel, nama-nama malaikat tidak dikenal, mereka juga tidak pernah disebutkan namanya dalam Kitab Suci ${ }^{14}$.

\footnotetext{
${ }^{13}$ Pat and David Aleander (Ed). The New Lion Handbook to The Bible ( UK: A Lion Book,1999), 274

${ }^{14}$ John Gill's Exposotion of the Bible, Colosian 2:18, diakses 23 Agustus 2019 https://www.biblestudytools.com/commentaries/gills-exposition-of-the-bible/colossians-2-18.htm1
} 
Sangatlah jelas bahwa penyembahan kepada para malaikat merupakan warisan dari ajaranajaran yang terdahulu yang dibawah oleh guru-guru palsu dan hal itu diterima oleh orang-orang yang ada di Kolose. Sementara itu pada bagian ini disebutkan oleh teolog lain bahwa penyembahan kepada para malaikat adalah bentuk dari gnostikisme baru yang tumbuh di Kolose. Tiga ciri khas gnostikisme yang baru mulai di Kolose yaitu ${ }^{15}$ :

1. Mempunyai sifat bertapa. $(2: 16,20-23)$

2. Taat kepada tatacara keagamaan. $(2: 16)$

3. Bersifat mistik (kebatinan).(2:18)

Dengan melihat struktur sosial kehidupan orang-orang di Kolose, berasal dari berbagai suku bangsa selain penduduk asli, adalah sangat mungkin terjadinya campur aduk kebudayaan atau tradisi yang tumbuh dalam kehidupan sosial. Masing-masing membawa budaya asli, selain budaya yang sudah dipengaruhi budaya dari bangsa lain, budaya masyarakat pribumi dan faktor sosial dan politik kemasyarakatan ini memungkinkan masyarakat berpindah pada kelompok yang lebih berpengaruh. Kecenderungan untuk bergabung dengan agama kongregasi rasional etis menjadi kian kuat menandai makin jauhnya seseorang dari kelas-kelas sosial yang menjadi pengusung tipe kapitalisme yang utamanya politik dalam orientasinya ${ }^{16}$. Pengaruh mempengaruhi antara budaya, tradisi dan agama yang hidup di tengah-tengah masyarakat di Kolose berimplikasi pada kehidupan jemaat. Hal ini telah ditandai dengan beberapa poin yang telah diuraikan di atas seperti sifat pertapa karena mewarisi penyembahan kepada malaikat, menjadi orang percaya tetapi masih membawa tradisi agama Yahudi seperti sunat dan tata cara lainnya. Inilah yang menjadi alasan esensi bagi Paulus menulis betapa pentingnya orang-orang percaya memiliki kehidupan "dipenuhi di dalam Kristus" yang memiliki korelasi yang kuat dengan tema utama yaitu Kristologi.

\section{Teologi Surat Kolose}

Surat untuk orang-orang Kolose adalah bersifat Kristologi yaitu surat yang berpusat pada hidup dan seluruh karya Kristus. Surat ini ditulis sewaktu Paulus masih dipenjara dan jemaat yang ada di Kolose adalah jemaat yang bukan didirikan oleh Paulus namun Paulus memiliki hubungan yang dekat dengan orang-orang yang ada di Kolose sehingga ia merasa perlu menuliskan surat ini supaya jemaat yang lagi bertumbuh tidak mudah diombang-ambingkan berbagai ajaran.

Sebagaimana telah diuraikan pada bagian sebelumnya bahwa orang-orang yang ada di Kolose ini memiliki sosiologi yang kompleks oleh karena tumbuhnya berbagai ajaran dari sub-sub sistem kemasyarakatan yang dipengaruhi oleh latar belakang kepercayaannya, maka di dalamnya terbangun persekutuan Kristen yang berkembang dengan baik. Tetapi di tengah pertumbuhan itu ada tantangan yang harus hadapi dan Paulus dalam suratnya menyerukan orang-orang percaya untuk tetap setia kepada Injil Yesus Kristus.

Ada beberapa hal yang telah disebutkan secara gamblang oleh Paulus tentang kehidupan sosial dan praktik-praktik yang bersifat sinkritisme terjadi dan mempengaruhi gereja, namun Paulus mengangkat sebuah tema yang memiliki substansi yang lebih tinggi dan mulia dari pada ajaran yang di bawah oleh bidat atau suku tertentu dan tema itu adalah" Dipenuhi di dalam Kristus". Tema ini menunjukan supremasi Kristus atas segala sesuatu, baik penguasa-penguasa atau pemerintahan, filsafat, hikmat, pengetahuan atau aturan-aturan keagamaan di luar Injil. Sebuah senjata yang tajam guna menangkal ajaran-ajaran sesat yang sedang mengancam iman orang-orang percaya yang ada di Kolose.

${ }^{15}$ Jarry Autrey. Surat Kiriman Penjara (Malang: Gandum Mas, 2001), 159

16 Max Weber, Sosiologi Agama A Handbook (Yogyakarta: IRCiSod, 2012), 276 


\subsection{Seluruh kepenuhan Allah ada dalam Kristus (1:19, 2:9)}

Apa yang diberitakan oleh para nabi dalam Perjanjian Lama, termasuk hukum atau aturan yang diterima dalam Perjanjian Lama merupakan sebuah bayangan yang akan terwujud di masa mendatang. Dan di surat Kolose di tulis salah satu tujuannya adalah menyingkapkan bayangan itu melalui kehadiran Kristus di dalam dunia. Penyingkapan ini ditunjukan melalui supremasi Kristus dan melalui supremasi ini menyatakan kepenuhan Allah di dalam Kristus. Supremasi Kristus terlihat pada bagian awal tulisan Paulus kepada jemaat yang ada di Kolose. Lembaga Alkitab Indonesia memberikan judul perikop tersebut dengan keutamaan Kristus (1:15-23). Pada bagian ini Kristus disebutkan lebih utama dari segala sesuatu yang diciptakan bahkan di dalam Kristus segala sesutau diciptakan baik di sorga maupun di bumi. Supremasi Kristus disebutkan mulai dari pre eksistensi dunia $(15,17)$, penciptaan (16) bahkan sesudah penciptaan, khususnya karya Kristus bagi orang-orang percaya yang adalah kepala tubuh (18), serta eskatologi $(3 ; 1,4)$ walupun tidak banyak disinggung dalam surat ini. Surat Kolose ini secara lengkap menyatakan supremasi Kristus mulai dari pre eksistensi dunia sampai kepada kesudahan alam. Supremasi ini sendiri menyatakan bagaimana kerajaan (pemerintahan) Allah nyata dalam dunia ini. Sebuah pemerintahan yang tidak di batasi oleh berbagai batasan, baik ruang maupun waktu. Dan supremasi Kristus ini menyatakan akan kekekalan dari pemerintahan kerajaan Allah di mana Kristus sendiri adalah Raja-Nya.

Supremasi Kristus ini juga merupakan sebuah penyingkapan rahasia yang tersembunyi (26), (2:3) dan di dalam Dia orang percaya mengalami kesempurnaan(28). Penyingkapan ini merupakan sebuah jawaban atas misteri Ilahi selama berabad-abad Supremasi Kristus ini menyatakan bahwa seluruh kepenuhan Allah ada dalam Kristus. Hal ini menegaskan akan inkarnasi itu sendiri. Firman yang menjadi manusia dan kepenuhan Allah ada dalam Kristus (Yohanes 1:14,16). Dari supremasi Kristus ini dimana seluruh kepenuhan Allah ada dalam Kristus menjadi dasar bahwa orang-orang percaya dapat mengalami kepenuhan Kristus melalui Roh Kudus.

\subsection{Orang percaya dipenuhi di dalam Kristus}

Paulus menyingkapkan seluruh kepenuhan Allah ada dalam Kristus sebab ia ingin menunjukan rahasia hubungan Kristus dengan orang-orang percaya. Dan hubungan ini memiliki makna yang sangat dalam bukan saja tentang Kristus dan orang percaya tetapi juga antara Allah dan manusia sebab Kristuslah pengantara yang sejati. Penyingkapan ini sangat tepat di tengah-tengah tumbuhnya ajaran sesat yang sedang merambah kehidupan orang-orang yang ada di Kolose sehingga mereka tidak mudah diombang-ambingkan oleh berbagai ajaran yang bersifat duniawi.

Rahasia hubungan Kristus dan orang percaya itu adalah "Dipenuhi di dalam Kristus" dasar teologi dipenuhi di dalam Kristus yaitu: Dan kamu telah dipenuhi di dalam Dia. Dialah kepala semua pemerintahan dan penguasa ( 2:10). Kepenuhan di dalam Kristus juga ditulis di dalam kitab yang lain. Efesus menyatakan: sampai kita semua telah mencapai kesatuan iman dan pengetahuan yang benar tentang Anak Allah, kedewasaan penuh, dan tingkat pertumbuhan yang sesuai dengan kepenuhan Kristus ( 4:13 ). Dari pada-Nyalah seluruh tubuh-yang rapi tersusun dan diikat menjadi. Satu oleh pelayanan semua bagiannya, sesuai dengan kadar pekerjaan tiap-tiap anggota menerima pertumbuhannya dan membangun dirinya dalam kasih (16).

Ada relasi yang terbangun melalui hubungan antara Allah - Kristus - Gereja (orang-orang percaya), sistimatika ini akan menolong untuk memahami bagaimana menjadi dipenuhi di dalam Kristus. Relasi tersebut adalah sebagai berikut: Kepenuhan Allah di dalam Kristus- kepenuhan Kristus di dalam kita. Kepenuhan Allah dalam Kristus karena Kristus adalah Allah sendiri, yaitu Allah yang berinkarnasi menjadi manusia dan oleh karena iman kepada Kristus maka kepenuhan Allah itu dapat kita alami namun kepenuhan itu terjadi melalui Kristus sehingga kepenuhan Kristus ada dalam diri kita. Yohanes 14: 21. Barangsiapa memegang perintah-Ku dan melakukan-Nya, dialah yang mengasihi Aku. Dan barang siapa mengasihi Aku, ia akan dikasihi oleh Bapa-Ku dan Aku pun akan mengasihi dia dan 
akan menyatakan diri-ku kepadanya. Yesus sendiri menyatakan hubungan antara Allah, diri-Nya dan orang-orang percaya. Kesatuan antara Allah dan umat-Nya. dalam Injil Yohanes mempertegas Firman yang mengatakan: Dipenuhi di dalam Dia.

Supremasi Kristus atas segala sesuatu adalah merupakan sentral pemberitaan Paulus kepada jemaat yang ada di Kolose namun dalam tulisan ini diangkat teologi "Dipenuhi di dalam Kristus" yang merupakan sub tema dari supremasi Kristus. Dipenuhi di dalam Kristus diangkat dalam tulisan ini agar orang-orang percaya difokuskan bagaimana menjalani hidup ini dengan tetap mengalami kepenuhan Kristus di tengah-tengah tantangan seperti juga yang sedang di hadapi oleh jemaat yang ada di Kolose. Apa yang ditulis oleh Paulus kepada jemaat yang ada di Kolose merupakan pembelajaran bagi orangorang percaya

Kata dipenuhi menggunakan kata pleroo yang memiliki arti dibuat penuh, dipenuhi, lengkap. Kata ini sebenarnya lebih menunjuk pada sesuatu yang kosong tetapi tersedia kepenuhan. Sehingga jika diterjemahkan langsung akan memiliki pengertian bahwa orang-orang di Kolose mengalami kekosongan. Dalam hal ini kekosongan itu diakibatkan oleh berbagai angin pengajaran yang menyesatkan, tradisi, mistik, dan lain-lain. Namun di dalam Kristus mereka dipenuhi. Inilah maksud dipenuhi di dalam Kristus.

Kepenuhan di dalam Kristus yang ditulis dalam Kolose 2:10, memiliki kesamaan dengan apa yang Paulus tulis kepada jemaat di Efesus. . . . Aku berdoa, supaya kamu dipenuhi di dalam seluruh kepenuhan Allah (Efesus 3:19). Mengenai kepenuhan Allah ini, Baxter menyatakan demikian: perkataan seluruh menyatakan bahwa kita dipenuhi hingga kepenuhan itu sempurna. Sekali-kali bukan bahwa hati kita yang sempit dan terbatas ini dapat menerima segala kepenuhan Allah! Tetapi kita dapat dipenuhi menurut kesanggupan kita menerimanya. Kita harus dipenuhi sampai puncak kesanggupan kita: dimiliki, dikuasai, dijiwai oleh Dia yang menjadi kepenuhan Allah dan "Kepala" dari segala yang ada ${ }^{17}$. Selanjutnya Baxter menjelaskan kepenuhan di dalam Dia yang terdapat dalam Kolose ini demikian: jika Kristus kepenuhan Allah secara jasmaniah, maka tidak ada satupun yang dapat ditambahkan kepada-Nya, dan jika orang beriman ada " dalam Dia" tak ada sesuatupun yang dapat ditambahkan kepadanya, karena segala sesuatu sudah dalam Dia ${ }^{18}$. Dari penjelasan Baxter tentang kepenuhan di dalam Kristus baik dalam surat Efesus maupun Kolose menjelaskan kepenuhan Kristus dapat dialami oleh orang-orang percaya sesuai dengan kesanggupan yang ada dalam diri kita, menyangkut keseluruhan hidup sehingga tidak ada yang dapat ditambahkan lagi sebab orang-orang percaya sudah ada dalam Kristus.

Dalam konteks surat Kolose ini Paulus menunjukan kepenuhan yang mereka alami sejak menerima Yesus Kristus antara lain

\section{a. Hidup tetap di dalam Dia (2:6)}

Rahasia kepenuhan Kristus di dalam hidup orang-orang percaya adalah tetap hidup di dalam Dia. Orang-orang Kolose diminta untuk tetap hidup di dalam Kristus. Bukan berarti selama ini mereka tidak hidup di dalam Kristus, mereka adalah jemaat yang mengalami pertumbuhan yang baik, tetapi dorongan untuk tetap hidup dalam Kristus karena saat itu mereka sedang diperhadapkan dengan berbagai tantangan hidup sehingga ketaatan hidup di dalam Dia sangat diperlukan.

\section{b. Di sunat dengan menanggalkan manusia lama (2:11).}

Adanya perdebatan tentang orang-orang Kristen dari kalangan Yahudi dengan tetap mempertahankan tradisi agama sebelumnya, terutama masalah sunat rupanya menyebar di mana orang Yahudi berdomisili. Permasalahan ini juga terjadi dengan orang-orang Kristen yang ada di Kolose.

\footnotetext{
${ }^{17}$ J. Sidlow Baxter. Menggali isi Alkitab, Roma sampai dengan Wahyu, jilid 4 (Jakarta: Yayasan Komunikasi Bina Kasih/ OMF, 2008), 114

${ }^{18}$ J. Sidlow Baxter, 140
} 
Paulus menegaskan bahwa anugerah itu telah datang, apa yang menjadi bayangan, termasuk sunat, sudah disingkapkan melalui kedatangan Kristus, kehidupan, kematian, kebangkitan dan kenaikan-Nya di surga. Sehingga Paulus menunjuk bahwa sunat yang harus dialami oleh orang percaya adalah sunat hati, menanggalkan semua kebiasaan manusia lama dan mengenakan manusia baru. Dari pada sekedar memotong sebagian kecil daging, sunat Kristen secara rohani berarti dikeluarkannya dosa dari hati dan mengambil bagian dalam kovenan baru ${ }^{19}$. Kepenuhan di dalam Kristus berarti menjadi ciptaan baru dan hidup di dalam kasih karunia yang disediakan.

\section{c. Di baptis melalui kematian dan kebangkitannya $(2: 12 ; 3: 1-4)$}

Apa arti di baptis melalui kematian dan kebangkitan Kristus? Apakah yang dimaksud oleh Paulus dalam bentuk harafiah atau merupakan simbol atas karya penebusan Kristus atas umat manusia, khususnya orang percaya? Jelas Paulus menggunakan simbol kematian dan kebangkitan Kristus sebagai pembebasan manusia dari ikatan dosa. Simbol kematian menyatakan bahwa dosa-dosa manusia turut dikuburkan oleh kematian Kristus, dan kebangkitan-Nya menyatakan bahwa apa yang turut dikuburkan dalam kematian-Nya kini tidak menguasai lagi manusia tetapi dengan kebangkitan-Nya maka orangorang percaya menjadi ciptaan baru sebab telah ditebus melalui kematian-Nya. Kematian dan kebangkitan Kristus menyatakan hubungan orang-orang percaya dengan Kristus sehingga mereka yang percaya diikat dalam hubungan tersebut dan menjadi satu dengan Kristus. Dengan simbol kematian dan kebangkitan Kristus maka manusia menjadi kepenuhan di dalam Kristus.

\section{d. Dipilih dan dikuduskan ( 3:12)}

Orang-orang percaya adalah orang-orang yang dipilih oleh Allah. Pilihan ini terjadi karena iman percaya sebagai respon atas kematian Kristus di atas kayu salib yang merupakan sebuah karya yang terjadi sekali untuk selamanya dan bagi semua orang.

Kristus menjamin bahwa mereka yang percaya kepada-Nya dipisahkan dan dikhususkan bagi kemuliaan-Nya. maka bagi orang-orang percaya di Kolose adalah umat Allah yang kudus, dikhususkan bagi pekerjaan mulia. Tidak ada alasan bagi mereka untuk menuruti ajaran-ajaran yang di bawah oleh guru-guru palsu yang ada di Kolose. Tetapi mereka harus mengarahkan pandangannya kepada supremasi Kristus atas segala sesuatu. Dengan demikian dipenuhi di dalam Kristus adalah telah mengalami penebusan melalui darah Kristus, dikuduskan dan hidup di dalam kasih karunia yang disediakan.

\section{e. Perkataan Kristus dengan segala kekayaan-Nya ( 3:16)}

Pada bagian ini Paulus menunjuk pada sesuatu yang lebih mulia dan agung dari pada segala filsafat atau pengetahuan yang orang-orang Kolose terima melalui guru-guru palsu. Paulus membandingkan bahwa perkataan Kristus dengan segala kekayaan-Nya telah mereka terima, dan yang mereka terima adalah Firman yang disingkapkan, apa yang belum disingkapkan akan disingkapkan pada waktunya. Inilah kekayaan yang ada dalam Kristus yang tidak ditemui melalui filsafat dan pengetahuan maupun kata-kata yang indah yang lagi populer di kalangan orang-orang Kolose.

\section{Peran orang percaya dalam masyarakat Kolose}

Struktur sosial dan keagamaan yang tumbuh dan berkembang di Kolose adalah struktur sosial dan keagamaan yang cukup kompleks permasalahannya dan di tengah-tengah kondisi yang demikian hiduplah suatu persekutuan Kristen yang disebut dengan orang-orang kudus oleh Rasul Paulus (1:2). Adalah sangat beralasan bagi Paulus menyebut orang-orang di Kolose sebagai orang-orang kudus sebab di tengah-tengah munculnya berbagai ajaran di masyarakat, orang-orang di Kolose tetap berpegang

${ }^{19}$ Earl D. Radmacher (Edit). The Nelson Studi Bible, New King James Version (Nashville: Thomas Nelson Publisher , 1997), 2014 terjemahan penulis 
pada kebenaran. Bahkan surat Kolose ini tidak hanya diterima dan dibacakan khusus untuk orang-orang Kolose saja, melainkan juga untuk dibacakan bagi jemaat di Laodikia (4:16)

Perubahan sosial dapat saja terjadi karena pembauran tradisi, budaya bahkan nilai-nilai dari suatu suku, bangsa dan agama. Tetapi Firman "dipenuhi di dalam Dia", yang menunjukan supremasi Kristus atas hidup orang percaya tidak boleh dikikis oleh berbagai angin ajaran yang muncul. Orangorang percaya di Kolose membuktikannya dalam hidup mereka. Dan itu dipertegas dalam pembukaan surat di Kolose (1:1-14)

Kini apa yang dapat dijabarkan dalam kehidupan orang-orang percaya di Kolose tentang "dipenuhi di dalam Kristus " terhadap sistim masyarakat yang memiliki struktur sosial dan keagamaan yang berbeda-beda?. Tugas panggilan orang-orang percaya di Kolose adalah membawa "dipenuhi di dalam Kristus" dalam kehidupan sehari hari guna menangkal berbagai ajaran yang tumbuh subur di dalam suatu sistem masyarakat. Kepenuhan ke Allahan dalam Kristus dan orang-orang percaya dipenuhi di dalam Kristus dengan indikator yang telah disebutkan pada bagian sebelumnya harus menjadi pola hidup sehari-hari. Hal ini dapat dilakukan sebab gereja dalam masyarakat yang luas merupakan sebuah sub sistem dan sub sistem dalam masyarakat dapat menggerakkan sistem yang lebih besar (masyarakat) melalui tindakan yang nyata.

Sejarah gereja mencatat bahwa panggilan dalam melaksanakan tugas transformasi membawa perubahan yang besar terhadap kehidupan masyarakat. Fungsi transformatif gereja terus terjadi secara berkelanjutan. Dalam konteks orang-orang di Kolose bagaimana mewujudkan "dipenuhi di dalam Kristus" yang telah mereka alami ditransformasikan dalam kehidupan sosial. Hal ini dapat diartikan bahwa mereka dapat mengubah bentuk kehidupan dengan mengganti nilai-nilai lama dan menanamkan nilai-nilai baru yang lebih bermanfaat sebagaimana Elizabeth K. Nottingham katakan ${ }^{20}$. Nilai-nilai lama seperti berpegang teguh pada filsafat dunia, warisan agama Yahudi seperti melaksanakan Taurat, Aturan makanan dan minuman serta hari raya dan beribadah kepada malaikat diganti dengan nilai-nilai hidup sebagai orang yang dipenuhi di dalam Kristus maka tugas panggilannya sebagai gereja yang transformatif merupakan perwujudan nilai-nilai kerajaan Allah di bumi ini. Gereja yang adalah sub sistem dalam masyarakat sanggup melaksanakan tugas transformatifnya dengan menghidupi suatu kehidupan dipenuhi di dalam Kristus dalam kehidupan sehari-hari maka gereja yang adalah sub sistem dalam masyarakat dapat menggerakan sistem masyarakat yang lebih luas dengan menghadirkan tandatanda kerajaan Allah dalam pelayanannya.

\section{Eksistensi gereja dalam melayani masyarakat}

Berdasarkan kajian pustaka surat Kolose maka gereja dalam melayani masyarakat harus memahami bahwa panggilan untuk melayani di dasarkan pada:

\subsection{Supremasi Kristus atas segala sesuatu}

Sebagaimana eksistensi jemaat di Kolose adalah jemaat yang hidup di suatu masyarakat yang kompleks dan menghadapi berbagai tantangan namun jemaat di Kolose adalah jemaat yang tetap setia pada misi Allah. Hal ini terjadi sebab jemaat di Kolose adalah jemaat yang memahami bahwa

\footnotetext{
${ }^{20}$ Elizabeth Nottingham. Agama dan Masyarakat. Rajawali Press, 1997

Fungsi transformatif disini diartikan dengan mengubah bentuk kehidupan baru atau mengganti nilai-nilai lama dengan menanamkan nilai-nilai baru yang lebih bermanfaat.
} 
pemrakarsa misi adalah Allah sendiri dan dalam misi supremasi Kristus ada dalam segala sesuatu dan atas segala sesuatu.

Supremasi Kristus nyata dari kepenuhan Allah berdiam dalam diri Kristus yang hadir dalam wujud daging dan ini menjadi model bagi orang percaya bahwa kepenuhan Allah dapat terwujud dalam hidup manusia.

Berdasarkan hal tersebut maka setiap orang percaya dipanggil untuk meninggikan Kristus dalam segala sesuatu dan atas segala sesuatu. Dalam berinteraksi di suatu masyarakat yang plural maka kepenuhan Kristus dalam diri orang percaya menjadi tanda yang nyata sehingga supremasi Kristus ada dalam segala sesuatu dan atas segala sesuatu.

\subsection{Supremasi Kristus dalam misi}

Ada dua hal penting yang perlu diperhatikan oleh gereja dalam melaksanakan mandat misi yaitu mandat misi itu sendiri dan perubahan yang terjadi secara global. Model-model misi yang diterapkan pada masa yang lampau ketika diterapkan dalam konteks kekinian akan menghadapi tantangan besar sebab perubahan terjadi secara terus menerus. Perlu menemukan model misi baru yang sesuai dengan konteks saat ini. Generasi milenial dengan karakter yang berbeda dengan generasi sebelumnya, generasi alpha yang akan muncul kemudian merupakan tantangan dan sekaligus peluang bagi gereja bila menemukan strategi yang tepat dalam melayani mereka. Berbagai model generasi akan terus muncul dan mereka akan membentuk struktur masyarakat dan gereja ada di dalamnya. Saatnya gereja untuk melihat bagaimana misi dilaksankan di era perubahan ini dan bagaimana supremasi Kristus tetap menjadi yang utama dalam misi

\subsection{Gereja memiliki strategi dalam menjalankan mandat misi}

Supremasi Kristus ada dalam segala sesuatu dan atas segala sesuatu adalah kunci bagi gereja dalam menjalankan mandat misi. Bila Kristus tetap bersupremasi dalam misi maka gereja akan tetap eksis bahkan semakin memperluas wilayah misinya. Agar Kristus tetap bersupremasi dalam misi maka gereja harus memilki strategi yang secara terus menerus di evaluasi sesuai dengan konteks masyarakat. Mayarakat di Kolose memiliki ciri tersendiri dan gereja dapat eksis di tengah-tengah masyarakat tersebut. Kini saatnya bagi gereja untuk menemukan model-model misi yang baru dalam melayani masyarakat yang memiliki nilai-nilai tersendiri yang terbentuk oleh generasi milenial dan alpha yang telah hadir dan akan membentuk sistim dan sub sistim masyarakat yang memiliki ciri tersendiri.

\section{Kesimpulan}

Gereja yang ada di Kolose adalah gereja yang belum lama berdiri dan mengalami pertumbuhan yang cepat. Namun di tengah-tengah pertumbuhannya tantangan demi tantangan datang bahkan memengaruhi kehidupan orang percaya. Hal ini sangat memungkinkan sebab mereka berasal dari berbagai suku dan latar belakang agama serta budaya yang berbeda.

Dalam menghadapi tantangan tersebut, Paulus menuliskan surat yang penekanannya pada supremasi Kristus atas segala kepercayaan yang masih diimani oleh beberapa orang di Kolose. Di penuhi di dalam Kristus adalah sentral pemberitaannya. Orang-orang percaya mengalami kehidupan kepenuhan di dalam Kristus sebagaimana kepenuhan Allah berdiam dalam Kristus. Supremasi Kristus berarti Kristus ada dalam segala sesuatu dan di atas segala sesuatu

Dipenuhi di dalam Kristus adalah pemberitaan yang diproklamirkan dalam melaksanakan tugas transformatif gereja. Persoalannya adalah bagaimana gereja yang ada dalam masyarakat mampu menggerakan kehidupan sosial sehingga terjadi transformasi hidup yang menyeluruh. Inilah panggilan 
gereja dalam melayani masyarakat dan dengan menempatkan supremasi Kristus atas segala sesuatu maka gereja dapat melayani masyarakat dengan baik. 
Voice Of Wesley: Jurnal Ilmiah Musik dan Agama | Vol. 3 No. 2

\section{DAFTAR PUSTAKA}

Aleander David and Pat (Ed). The New Lion Handbook to The Bible, UK: A Lion Book. 1999

Autrey Jarry. Surat Kiriman Penjara, Malang: Gandum Mas, 2001

Baxter Sidlow J. Menggali isi Alkitab, Roma sampai dengan Wahyu, jilid 4, Jakarta: Yayasan Komunikasi Bina Kasih/ OMF, 2008

Bosch David J, Transformasi Misi Kristen, Sejarah Teologi Misi yang Mengubah dan Berubah, Jakarta: BPK, 2015

Chapman Adina. Pengantar Perjanjian Baru, Bandung: Yayayasan Kalam Hidup, 1995

Haryanto Sindung. Sosiologi Agama dari Klasik Hingga Postmodern. Yogyakarta: Arr- Ruzz Media, 2015

Martono Nanang. Sosiologi Perubahan Sosial, Perspektif Klasik, Modern, Posmodern dan Poskolonial, Jakarta: PT RajaGrafindo Persada, 2016

N.T Wright. Tyndale New Testament Commentaries, Colossians and Philemon, England: Inter Varsity Press, 1997

Nottingham Elizabeth. Agama dan Masyarakat. Rajawali Press, 1997

Schwatskopf Luther E. The Letter of Paul to the Collossian, Living Way Bible Study, La Mirada Canada, 2014

Ritzer George, Goodman Douglas J. Teori Sosiologi Moderen. Jakarta: Kencana Prenada Media Group, 2004

Radmacher Earl D (Edit). The Nelson Studi Bible, New King James Version, Nashville: Thomas Nelson Publisher, 1997

Zed Meztika, metode penelitian kepustakaan, Jakarta: Yayasan Obor Indonesia, 2008

Weber Max, Sosiologi Agama, Yogyakarta: IRCiSoD, 2012

Benson Commentary Colossian 2:4-5, diakses 22 Agustus 2019

https://biblehub.com/commentaries/colossians/2-4.htm

John Gill's Exposotion of the Bible, Colosian 2:18, diakses 23 Agustus 2019

https://www.biblestudytools.com/commentaries/gills-exposition-of-the-bible/colossians-2-

18.html 